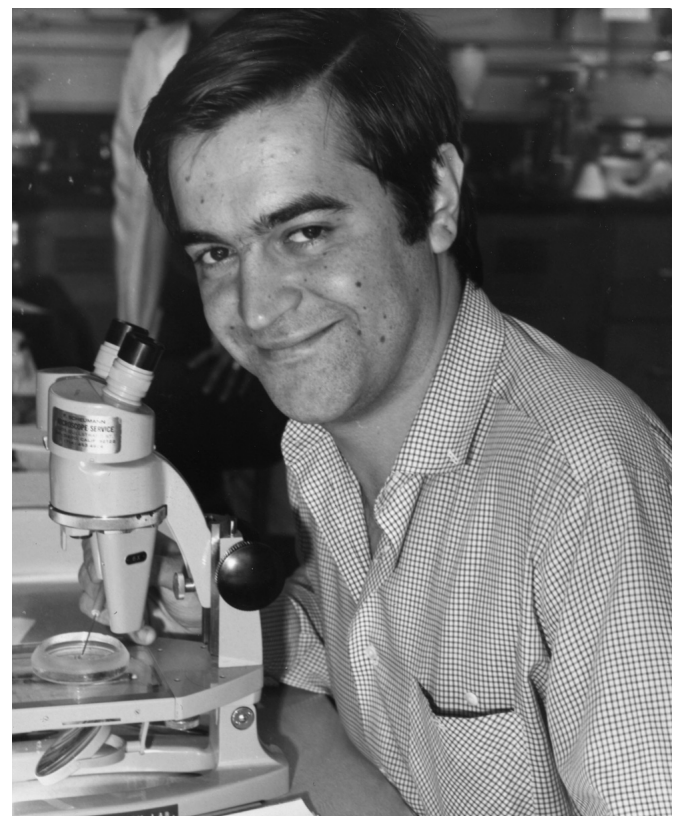

\title{
Pere Rubiés Guardiola (1949-2007)
}

Our companion and friend Pere died on 8 November of this year. Born in Barcelona on 25 March 1949, Pere began his career in the field of marine biology in the early 1970s, when he was finishing his degree in Biological Sciences at the University of Barcelona. At that time the Instituto de Investigaciones Pesqueras (currently the Institut de Ciències del Mar) was beginning a series of oceanographic studies on the coasts of the western Sahara for which Pere signed up, showing his usual enthusiasm. Those were difficult times for research in Spain, but tremendously exciting. They were the first years of the R/V Cornide de Saavedra, the first large Spanish oceanographic vessel. Thanks to the enthusiasm of Drs. Ballester, Bas and Margalef, this period laid the bases of Spanish oceanography as we know it today. Pere participated in several of these African campaigns and his personal charms and friendliness soon made him an essential colleague whom many wanted on their team. He went straight into working on plankton studies, and specialised in ichthyoplankton under the auspices of Drs. Vives and Bas.

Pere formed a team with Isabel Palomera and together they began to study the ichthyoplankton of the Saharan coasts and the northwestern Mediterranean. In November 1979 he led his first oceanographic campaign in Namibian waters (Benguela I) on board the R/V García del Cid. He thus became a member of the team studying the fisheries of these waters, participating in many of the campaigns carried out annually by the Institut de Ciències del Mar of Barcelona, including the SNEC surveys, which he directed on board the South African oceanographic vessel R/V Africana. Within the framework of these studies he formed part of the Spanish scientific delegation that took part in the annual meetings of the ICSEAF (International Commission for the Southeast Atlantic Fisheries), where for eight years he was chair of the Environment section. With Drs. Bas and Margalef, he edited the two books that included the publications presented at the international symposium on the most important areas of upwelling in West Africa (Cap Blanc and Benguela). Later, between 1989 and 1995 he was a member of the Editorial Committee of Scientia Marina.

Pere was above all a good friend to his friends, an ideal companion on expeditions and at meetings. His friendliness earned him the esteem of his col- 
leagues, at home and abroad, and those of us who worked with him were always grateful for his lucidity and ability to solve problems and conflicts. He was a devoted bridge player and amateur linguist, and always found the right thing to say at the right moment during the-sometimes difficult-meetings of the ICSEAF. We will miss you, Pere and our message to you, in the Latin that you were so fond of, is Amico firmo nihil emi melius potest.

ENRIQUE MACPHERSON and MARIO MANRÍQUEZ 